Jurnal Kesehatan

Volume 12, Nomor 1, Tahun 2021

ISSN 2086-7751 (Print), ISSN 2548-5695 (Online) http://ejurnal.poltekkes-tjk.ac.id/index.php/JK

\title{
Metode Distraksi Audio dengan Media Dzikir Jaly terhadap Penurunan Kecemasan Persalinan Kala I Fase Aktif
}

\section{Audio Distraction Method with Dzikr Jaly Media to Decrease Active Phase I Labor Anxiety}

Elita Vasra $^{1}$, Nurul Komariah ${ }^{2}$, Ajeng Rizky Parawansyah $^{3}$

Prodi D-IV Kebidanan, Politeknik Kesehatan Palembang, Indonesia

\begin{tabular}{l} 
ARTICLE INFO \\
\hline Article history \\
Received date \\
13 Nov 2020 \\
Revised date \\
15 Nov 2020 \\
Accepted date \\
06 Apr 2021 \\
\hline
\end{tabular}

Keywords:

Anxiety;

Distraction;

Dzikr;

Labour.

\section{Kata kunci:}

Kecemasan;

Distraksi;

Dzikir;

Persalinan.

\begin{abstract}
ABSTRAK
Anxiety can be experienced by someone in any situation especially in mothers who will face childbirth. Excessive anxiety in expectant mothers can also slow down cervical dilatation and further facilitate the childbirth process. Based on this, anxiety should be addressed to avoid complications during childbirth. One of the efforts in alleviating anxiety in maternity mothers is to use distraction techniques with the media of Dzikr. This study aims to know the effect of the audio distraction technique with the media of dzikr jaly on anxiety in childbirth during the active phase at Sekayu General Hospital in 2020. This research used a pre-experimental one-group pretest-posttest design. The sample was taken from the population that met the inclusion criteria, with 33 people with purposive sampling. The results of the study using t-test obtained the value of Significance 0.000 ( $\rho$-value $<0,05)$ means there is a meaningful difference between decreased maternity anxiety when the active phase to before and after therapy. Audio distraction technique with media of Dzikr Jaly affects the decreased anxiety in maternity mothers during the active phase of the Sekayu General Hospital.
\end{abstract}

\begin{abstract}
Kecemasan dapat di alami oleh seseorang pada situasi apapun terutama pada ibu yang akan menghadapi persalinan. Kecemasan yang berlebihan pada ibu hamil juga dapat memperlambat dilatasi servik sehingga semakin memperlama proses persalinan. Berdasarkan hal tersebut, maka kecemasan harus diatasi agar tidak terjadi komplikasi pada saat persalinan. Salah satu upaya dalam mengurangi kecemasan pada ibu bersalin adalah dengan menggunakan teknik distraksi dengan media dzikir. Tujuan penelitian ini ntuk mengetahui pengaruh teknik distraksi audio dengan media dzikir jaly terhadap Kecemasan Persalinan Kala I Fase Aktif di RSUD Sekayu Tahun 2020. Penelitian ini menggunakan metode penelitian pre-eksperimen one group pretest-posttest design. Sampel diambil dari populasi yang memenuhi kriteria inklusi, sebanyak 33 orang dengan purposive sampling. Hasil penelitian menggunakan uji t test diperoleh nilai significancy $0,000(\rho$-value $<0,05)$ artinya ada perbedaan yang bermakna antara penurunan kecemasan ibu bersalin kala I fase aktif terhadap sebelum dan sesudah diberikan terapi. Teknik distraksi audio dengan media dzikir jaly berpengaruh terhadap penurunan kecemasan pada ibu bersalin kala I fase aktif di RSUD Sekayu.
\end{abstract}

Corresponding Author:

Elita Vasra

Prodi D-IV Kebidanan, Politeknik Kesehatan Palembang, Indonesia

Email: elita@poltekkespalembang.ac.id

\section{PENDAHULUAN}

Mortalitas dan morbiditas pada wanita hamil dan bersalin merupakan masalah besar di negara berkembang. Persalinan lama merupakan salah satu penyebab tingginya Angka Kematian
Ibu (AKI) di Indonesia. Beberapa faktor yang mempengaruhi terjadinya persalinan lama antara lain adalah power atau kekuatan ibu dan psikologis ibu yang tidak siap menghadapi persalinan. Diketahui pada wanita bersalin khususnya primigravida, mereka secara aktif 
mempersiapkan diri untuk menghadapi proses persalinan walaupun persalinan adalah sebuah proses yang alami, tetapi seringkali ibu hamil tidak dapat menghilangkan rasa khawatir dan cemas yang dapat membuat ibu tidak berkonsentrasi dengan baik dalam menghadapi proses persalinan (Heriani, 2016).

Penelitian yang dilakukan Heriani (2016) menunjukkan bahwa proporsi ibu primigravida ternyata mengalami kecemasan lebih tinggi dibandingkan ibu multigravida. Maka dari itu, kecemasan harus diatasi agar tidak terjadi nyeri yang berlebihan pada saat proses persalinan. Menurut Ash-Shiddieqy (2001) dalam Niko (2018), salah satu intervensi yang telah terbukti efektif untuk mengurangi kecemasan dan telah sering digunakan adalah dzikir. Dzikir ialah mengingat nikmat-nikmat Tuhan. Lebih jauh, berdzikir meliputi pengertian menyebut lafallafal dzikir dan mengingat Allah dalam setiap waktu, takut dan berharap hanya kepada-Nya, merasa yakin bahwa diri manusia selalu berada di bawah kehendak Allah dalam segala hal dan urusannya.

Penelitian yang dilakukan oleh Nurbaiti (2015) di RSUD Tangerang menyatakan dzikir efektif menurunkan tingkat kecemasan dan nyeri persalinan pada ibu primigravida selama proses persalinan. Ibu primigravida yang dilakukan intervensi dzikir mengalami kecenderungan mengalami kecemasan ringan dalam menghadapi proses kelahiran bayi, sedangkan ibu primigravida yang tidak dilakukan terapi dzikir cenderung mengalami kecemasan sedang.

Bedasarkan latar belakang di atas menarik perhatian peneliti untuk melakukan penelitian tentang "Pengaruh Teknik Distraksi Audio Dengan Media Dzikir Jaly terhadap Penurunan Kecemasan Persalinan Kala I Fase Aktif di BPM Kota Palembang Tahun 2020".

\section{METODE}

Penelitian ini merupakan penelitian kuantitatif dengan pre eksperimental design. Rancangan penelitian menggunakan one group pre-test post-test design. Penelitian ini tidak ada kelompok pembanding (kontrol), sebelum melaksanakan intervensi dilakukan observasi pertama (pre-test). Kemudian di lakukan observasi kedua (post-test) setelah intervensi (Notoatmodjo, 2018).

Pada penelitian ini ibu bersalin sebelum diberikan terapi non-farmakologis (terapi dzikir) akan diukur tingkat kecemasannya dengan menggunakan alat ukur kecemasan Pregnancy
Anxiety Questionnare-Revised (PRAQ-R). Jika telah didapatkan hasil pengukuran sebelum diberikan perlakuan, selanjutnya ibu diberikan terapi dzikir. Setelah diberikan terapi dzikir, tingkat kecemasan ibu diukur kembali. Penelitian telah dilakukan pada bulan Januari-Maret Tahun 2020, bertempat di RSUD Sekayu.

Populasi dalam penelitian ini adalah seluruh ibu bersalin kala I fase aktif di RSUD Sekayu Tahun 2020. Peneliti menetapkan jumlah sampel penelitian ini sebesar 30 responden sesuai dengan jumlah minimal sampel penelitian eksperimen sederhana. Untuk menghindari adanya sampel yang drop out maka dilakukan koreksi sebesar 10\% (Sastroasmoro, 2011). Besar sampel ditambah dengan antisipasi drop out sebesar $10 \%$ sehingga sampel minimal yang diperlukan adalah 33 responden.

Adapun kriteria sampel pada penelitian ini yaitu: kriteria inklusi yang terdiri dari bu primipara, ibu inpartu kala I fase aktif (pembukaan $4-7 \mathrm{~cm}$ ), Ibu bersalin fisiologis, ibu bersalin yang memiliki skor kecemasan $>11$, ibu bersalin yang bersedia menjadi responden, dapat berkomunikasi dengan baik, ibu yang beragama Islam; sedangkan kriteria eksklusi terdiri dari ibu dengan penyakit kronik, dan ibu dengan komplikasi kehamilan.

Alat dan bahan yang digunakan dalam penelitian ini adalah lembar pengukuran tingkat kecemasan dengan menggunakan Pregnancy Anxiety Questionnare-Revised (PRAQ-R).

Penelitian Huizink (2016) menjelaskan bahwa skala PRAQ-R merupakan instrumen yang digunakan untuk menilai dan mengidentifikasi kecemasan secara spesifik pada kehamilan wanita primigravida. Menurut skala PRAQ-R terdapat 11 item yang nampak pada ibu bersalin. Setiap item yang diobservasi diberi 5 tingkatan skor antara 1 sampai dengan 5. Skala PRAQ-R memiliki nilai uji validitas $(0,77)$ dan uji reliabilitas $(0,85)$ dimana nilai tersebut dinyatakan memuaskan dan layak untuk digunakan. Jadi pada penelitian ini peneliti tidak perlu melakukan uji validitas dan reliabilitas.

Penelitian ini telah melewati kaji etik dan mendapatkan Ethical Approval dengan nomor 052/KEPK/Adm2/II/2020 oleh Komite Etik Penelitian Kesehatan Politeknik Kesehatan Kementerian Kesehatan Palembang.

Analisis data yang digunakan yaitu analisis univariat dan bivariat. Analisis univariat pada penelitian ini yaitu variabel independen (terapi dzikir) dan variabel dependen (tingkat kecemasan pada ibu bersalin). Data numerik akan dilakukan uji normalitas data. Apabila distribusi data normal, ukuran pemusatan dan ukuran 
penyebaran yang digunakan adalah mean dan standar deviasi. Namun apabila distribusi data tidak normal, ukuran pemusatan dan ukuran penyebaran yang digunakan adalah median dan min-max. Analisis bivariat pada penelitian ini untuk mengetahui apakah ada pengaruh variabel independent (terapi dzikir) terhadap variabel dependen (kecemasan ibu bersalin) dengan tingkat kemaknaan $\alpha \leq 0,05$ dan CI 95\% maka terdapat pengaruh yang bermakna antara variabel independen dengan variabel dependen. Jika $p$ value $>\alpha$, maka tidak terdapat pengaruh antara variabel independent dengan variabel dependen.

Uji statistik yang digunakan yaitu uji parametrik dengan hipotesis komparatif berpasangan. Uji statistik yang digunakan adalah uji $t$ berpasangan. Namun apabila saat pengolahan data ditemukan distribusi data tidak normal, maka digunakan uji statistik alternatif yaitu uji Wilcoxon.

HASIL

Tabel 1. Gambaran Karakteristik Responden

\begin{tabular}{lrc}
\hline Karakteristik & \multicolumn{1}{c}{ f } & $\%$ \\
\hline Usia & & \\
$\quad<20$ Tahun & 21 & 63,6 \\
21-35 Tahun & 12 & 36,4 \\
Pendidikan & & \\
$\quad$ SMP & 7 & 21,2 \\
SMA & 21 & 63,7 \\
$\quad$ Perguruan tinggi & 5 & 15,1 \\
Pekerjaan & & \\
Bekerja & 6 & 18,1 \\
Tidak Bekerja & 27 & 81,9 \\
Pembukaan & & \\
Pembukaan 4 & 6 & 18,2 \\
Pembukaan 5 & 7 & 21,2 \\
Pembukaan 6 & 9 & 27,3 \\
Pembukaan 7 & 10 & 33,3 \\
\hline
\end{tabular}

Berdasarkan tabel 1 diketahui karakteristik responden yaitu mayoritas usia $<20$ tahun sebanyak 21 responden $(63,6 \%)$. Selanjutnya mayoritas responden berpendidikan SMA sebanyak 21 responden (63,7\%). Kemudian mayoritas responden yang tidak bekerja atau sebagai IRT sebanyak 27 responden $(81,9 \%)$. Kemudian mayoritas responden yang menjadi sampel dalam fase aktif pembukaan $7 \mathrm{~cm}$ sebanyak 10 responden $(33,3 \%)$.
Tabel 2. Nilai Pre-Intervensi dan PostIntervensi Terapi Dzikir terhadap Kecemasan Persalinan

\begin{tabular}{cccc}
\hline \multicolumn{1}{c}{ Variabel } & n & Mean & SD \\
\hline Pre-Intervensi & 33 & 33,85 & 5,669 \\
Post-Intervensi & 33 & 28,76 & 5,244 \\
\hline
\end{tabular}

Berdasarkan tabel 2 dapat diketahui bahwa nilai rata-rata kecemasan ibu sebelum dilakukan intervensi terapi dzikir adalah 33,85 dengan nilai standar deviasi 5,669. Sedangkan nilai rata-rata kecemasan ibu setelah dilakukan intervensi terapi dzikir adalah 28,76 dengan nilai standar deviasi 5,244. Dari tabel tersebut dapat dilihat bahwa terlihat penurunan nilai rata-rata atau mean dan standar deviasi atau simpangan baku sebelum intervensi dan sesudah intervensi.

Tabel 3. Pengaruh Terapi Dzikir terhadap Tingkat Kecemasan Ibu Bersalin

\begin{tabular}{cccc}
\hline Variabel & $\mathbf{n}$ & $\begin{array}{c}\text { Mean } \\
(\text { SD })\end{array}$ & p-value \\
\hline Pre-Intervensi & 33 & $33,85(5,669)$ & 0,000 \\
Post-Intervensi & 33 & $28,76(5,244)$ & \\
\hline
\end{tabular}

Berdasarkan tabel 3 dapat diketahui nilai rata-rata sebelum diberikan terapi dzikir adalah 33,85 dengan nilai standar deviasi atau simpangan baku 5,669 sedangkan setelah diberikan terapi dzikir nilai rata-rata yang didapat adalah 28,76 dengan nilai standar deviasi atau simpangan baku 5,244.

Uji $t$ berpasangan dan diperoleh nilai significancy $\rho$-value $=0.000 \quad(\rho \leq 0,05) \quad$ sehingga ada perbedaan yang bermakna pada rata-rata tingkat kecemasan terapi dzikir pada kala I fase aktif di RSUD Sekayu 2020.

\section{PEMBAHASAN}

\section{Gambaran Karakteristik Responden}

\section{Usia}

Dari hasil analisis karakteristik usia, didapatkan mayoritas responden berusia <20 tahun yaitu sebanyak 21 orang, berusia 21-35 tahun sebanyak 12 orang. Selanjutnya diketahui pula hubungan usia dengan tingkat kecemasan menunjukkan sebagian besar responden dengan usia $<20$ tahun. Bila dipandang dari sisi teori dan penelitian terkait, penelitian ini sejalan dengan hal tersebut.

Ibu yang usia $<20$ tahun memiliki perasaan cemas dan takut karena kondisi fisik yang belum siap serta organ reproduksinya masih dalam tahap 
perkembangan. Hal ini dapat memengaruhi lahan persepsi ataupun tingkat kecemasan seseorang. Berbeda dengan ibu berusia 21-35 tahun yang secara fisik sudah siap hamil karena organ reproduksinya sudah terbentuk (Rahmitha, 2017).

Usia adalah lamanya waktu hidup yaitu terhitung sejak lahir sampai dengan sekarang. Semakin bertambah usia semakin berkembang pula daya tangkap dan pola pikirnya, sehingga pengetahuan yang diperoleh semakin membaik (Rosa, 2015).

Usia merupakan salah satu faktor yang memengaruhi perilaku kesehatan seseorang, seseorang yang menjalani hidup secara normal dapat diasumsikan bahwa semakin lama hidup maka pengalaman akan semakin banyak, pengetahuan semakin luas, keahlian semakin mendalam dan kearifan semakin membaik dalam pengambilan keputusan tindakannya (Rosa, 2015).

Usia seseorang memengaruhi kesiapan fisik dan psikologis untuk melahirkan. Kecemasan ibu menjelang proses persalinan dipengaruhi oleh beberapa faktor, salah satunya adalah usia. Kehamilan pada usia kurang dari 20 tahun akan memberi dampak perasaan takut dan cemas menjelang persalinan, karena pada usia ini kondisi fisik belum sempurna untuk siap melahirkan serta pada usia ini merupakan kategori usia kehamilan dengan resiko tinggi untuk melahirkan (Heriani, 2016).

Hal ini sejalan dengan penelitian Handayani (2015) terhadap 64 responden dengan judul faktor yang berhubungan dengan tingkat kecemasan menjelang persalinan pada ibu primigravida trimester III di Puskesmas Lubuk Buaya Padang Tahun 2015 mendapatkan hasil $\mathrm{p}$ value dengan uji Chi-Square yaitu 0,000, artinya terdapat hubungan yang bermakna antara usia ibu dengan tingkat kecemasan menjelang persalinan di wilayah kerja Puskesmas Lubuk Buaya Padang Tahun 2015 (Handayani, 2015).

Dari hasil penelitian, teori dan penelitian terkait, peneliti berpendapat bahwa usia merupakan faktor yang memengaruhi perilaku dan kesiapan seseorang dalam menghadapi persalinan. Termasuk juga cara seseorang dalam mengatasi kecemasan tersebut selama persalinan.

\section{Pendidikan}

Berdasarkan analisa karakteristik pendidikan responden, didapatkan hasil bahwa mayoritas responden berpendidikan SMA sebanyak 21 orang, SMP sebanyak 7 orang, dan Perguruan Tinggi sebanyak 5 orang. Dari hasil analisis karakteristik responden berdasarkan pendidikan, dalam penelitian ini hubungan pendidikan dengan tingkat kecemasan menunjukkan sebagian besar responden dengan latar belakang pendidikan SMA. Bila dipandang dari sisi teori dan penelitian terkait, penelitian ini sejalan dengan hal tersebut.

Pendidikan merupakan salah satu aspek sosial yang dapat memengaruhi tingkah laku manusia dalam melakukan respon terhadap sesuatu. Pendidikan juga memengaruhi persepsi dan cara berpikir dalam mengambil keputusan. Semakin tinggi pendidikan ibu maka semakin tinggi tingkat pengetahuannya, karena memungkinkan ibu untuk mengantisipasi diri dalam menghadapi kecemasan (Bidjuni, 2014).

Pendidikan dan pengalaman memengaruhi pengetahuan seseorang dalam menghadapi proses persalinan. Pendidikan membantu ibu untuk lebih bisa memahami penjelasan yang diberikan. Tingkat kecemasan ibu bersalin akan meningkat jika ia tidak memahami apa yang terjadi pada dirinya atau yang disampaikan pada dirinya. Ibu bersalin memerlukan bimbingan dari keluarga dan penolong persalinan agar ia dapat menerima keadaan yang terjadi selama persalinan dan memahaminya maka diperlukan pengetahuan yang cukup sehingga ia dapat beradaptasi terhadap perubahan yang terjadi pada dirinya (Fitriana, 2018).

Menurut penelitian Heriani (2016) terhadap 45 responden dengan judul anxiety in nearly of labor based on parity, age and level of education menyebutkan bahwa pendidikan ibu mendapatkan hasil (p-value $=0,05), \quad$ artinya terdapat hubungan yang bermakna dengan tingkat kecemasan ibu dalam menghadapi proses persalinan (Heriani, 2016).

Penelitian ini sejalan dengan penelitian yang dilakukan oleh Reska Handayani tahun 2015 terhadap 64 responden dengan judul faktor yang berhubungan dengan tingkat kecemasan menjelang persalinan pada ibu primigravida trimester III di Puskesmas Lubuk Buaya Padang Tahun 2015, didapatkan bahwa jenjang pendidikan seseorang merupakan gambaran dari pengetahuan dan pemahaman yang dimilikinya. Hal ini terbukti dari jawaban kuisioner yang diisi oleh respoden menunjukkan bahwa responden yang pendidikannya termasuk kategori rendah akan mengalami tingkat kecemasan yang berat (Handayani, 2015).

Berdasarkan teori dan penelitian terkait, peneliti berpendapat bahwa pendidikan merupakan faktor yang memengaruhi pengetahuan ibu dalam menghadapi persalinan dan kemampuan ibu untuk menerima informasi dengan baik. Hal tersebut dapat diamati ketika peneliti memberikan informasi dan berinteraksi 
dengan responden dalam mengurangi tingkat kecemasan ibu bersalin.

\section{Pekerjaan}

Berdasarkan analisa karakteristik pekerjaan responden, didapatkan hasil bahwa mayoritas responden tidak bekerja sebanyak 26 orang, sedangkan responden yang bekerja sebanyak 7 orang. Dari hasil analisis karakteristik responden berdasarkan pekerjaan, dalam penelitian ini hubungan pekerjaan dengan tingkat kecemasan menunjukkan sebagian besar responden tidak bekerja. Bila dipandang dari sisi teori dan penelitian terkait, penelitian ini sejalan dengan hal tersebut.

Mayoritas ibu yang tidak bekerja akan lebih banyak mengalami kecemasan dibandingkan ibu yang bekerja. Karena bekerja dapat mengalihkan perasaan cemas yang dialami oleh ibu karena aktivitas yang menyita waktu. Ibu yang bekerja dapat berinteraksi dengan orang lain sehingga dapat menambah pengetahuan mengenai kehamilan, selain itu dengan bekerja dapat menambah penghasilan keluarga untuk mencukupi kebutuhan sebelum dan sesudah persalinan (Said, 2015).

Sosial ekonomi menjadi salah satu faktor yang memengaruhi kecemasan. Meskipun ibu mengetahui proses persalinan dengan baik, jika secara sosial ekonomi belum siap karena tidak memiliki biaya untuk proses persalinan, kemungkinan yang tidak cemas menjadi cemas dan yang sudah cemas akan menjadi lebih cemas. Budaya dapat pula ikut berperan dalam memengaruhi kondisi ibu bersalin sehingga dapat menimbulkan kecemasan. Dukungan sosial diperlukan dalam upaya memberikan ketenangan pada ibu bersalin (Fitriana, 2018).

Menurut penelitian yang dilakukan oleh Hasim (2018) mengenai gambaran kecemasan ibu hamil terhadap 71 responden, didapatkan hasil bahwa ibu yang tidak bekerja sebanyak 50 responden $(83,3 \%)$ mengalami cemas lebih tinggi dibandingkan ibu yang bekerja. Responden yang bekerja memungkinkan ibu mendapatkan informasi dan pengalaman tentang kehamilan dari orang lain dibandingkan responden yang tidak bekerja (Hasim, 2018).

Penelitian ini sejalan dengan penelitian Said (2015), didapatkan bahwa dari 9 responden ibu hamil primigravida yang bekerja lebih banyak tidak mengalami kecemasan yaitu sebanyak 6 orang $(66,7 \%)$, sedangkan dari 31 responden ibu hamil primigravida yang tidak bekerja, lebih banyak yang mengalami kecemasan yaitu sebanyak 16 orang $(51,6 \%)$ (Said, 2015).
Dari hasil penelitian, teori dan penelitian terkait, peneliti berpendapat bahwa pekerjaan bisa menjadi salah satu faktor penyebab kecemasan. Berdasarkan informasi yang didapat dari responden yang bekerja, mereka mengatakn stress disebabkan oleh beban pekerjaan, sehingga dapat memengaruhi perasaan cemas dalam menghadapi proses persalinan. Lain hal nya dengan ibu rumah tangga (tidak bekerja), kebanyakan dari mereka berpendapat kecemasan yang mereka alami salah satunya disebabkan oleh masalah ekonomi.

\section{Pembukaan}

Berdasarkan analisa karakteristik pembukaan responden, didapatkan hasil bahwa mayoritas responden dalam pembukaan $7 \mathrm{~cm}$ sebanyak 10 orang, pembukaan $6 \mathrm{~cm}$ sebanyak 9 orang, pembukaan $5 \mathrm{~cm}$ sebanyak 7 orang, dan pembukaan $4 \mathrm{~cm}$ sebanyak 6 orang. Dari hasil analisis karakteristik responden berdasarkan pembukaan, dalam penelitian ini hubungan pembukaan dengan tingkat kecemasan menunjukkan sebagian besar responden berada dalam pembukaan 7. Bila dipandang dari sisi teori dan penelitian terkait, penelitian ini sejalan dengan hal tersebut.

Semakin besar pembukaan ibu, maka ibu biasanya akan semakin merasakan perasaan cemas dan takut akan hal yang akan dihadapinya. Kecemasan yang biasanya akan ibu rasakan pada saat pembukaan yang terus bertambah antara lain seperti membayangkan proses persalinan, membayangkan sakitnya proses persalinan, kekhawatiran mengenai kondisi bayi, serta kekhawatiran untuk dapat melahirkan secara normal. Ekspresi kecemasan akan semakin terlihat pada ibu saat mendekati proses persalinan (Sagita, 2018).

Pembukaan pada saat proses persalinan merupakan sesuatu yang sangat memengaruhi kemajuan suatu proses persalinan. Membukanya leher rahim sebagai respon kontraksi yang berkembang. Serviks menjadi matang selama periode yang berbeda-beda selama persalinan, kematangan serviks mengindikasikan kesiapan untuk persalinan. Dari hasil penelitian dan teori, peneliti berpendapat bahwa pembukaan merupakan faktor yang memengaruhi kecemasan ibu dalam menghadapi proses persalinan. Hal tersebut dapat diamati ketika peneliti melakukan pengambilan sampel dan berinteraksi dengan responden. 


\section{Pengaruh Dzikir Jaly terhadap Penurunan Tingkat Kecemasan Ibu Bersalin Sebelum dan Sesudah Diberikan}

Berdasarkan hasil analisis bivariat, didapatkan penurunan tingkat kecemasan ibu menjelang persalinan setelah dilakukan intervensi. Mayoritas rata-rata tingkat kecemasan responden sebelum dilakukan intervensi adalah 33,85, sedangkan setelah dilakukan intervensi rata-rata tingkat kecemasan responden menjadi 28,76 .

Dari uji $t$ berpasangan diperoleh nilai $p$ value $=0,000 \quad(\leq 0,05)$ yang berarti terdapat perbedaan yang bermakna rata-rata kecemasan ibu menjelang persalinan sebelum dan setelah diberikan intervensi. Dengan demikian disimpulkan adanya pengaruh dari teknik distraksi audio dengan media dzikir jaly terhadap penurunan kecemasan persalinan kala I fase aktif di RSUD Sekayu tahun 2020.

Cemas dalam penelitian ini berhubungan dengan proses persalinan. Cemas timbul dari perasaan takut terhadap proses persalinan. Kecemasan dan kekhawatiran pada ibu hamil apabila tidak ditangani secara serius akan membawa dampak dan pengaruh terhadap fisik dan psikis, baik pada ibu maupun janin. Ibu yang mengalami kecemasan atau stres, akan mempengaruhi hipotalamus untuk merangsang kelenjar endokrin yang mengatur kelenjar hipofise. Reaksi ini menyebabkan peningkatan produksi hormon yang mempengaruhi sebagian besar organ tubuh, seperti jantung yang berdebar, denyut nadi dan nafas yang cepat, keringat berlebih, dan lain-lain. Selain itu, juga akan mengakibatkan terjadinya vasokontriksi yang menyebabkan gangguan aliran darah ke dalam rahim, sehingga oksigen yang diterima janin akan minim atau terganggu (Niko, 2018).

Pada penelitian ini, peneliti menggunakan dzikir untuk menurunkan kecemasan. Dzikir dipilih karenan pelafalan berulang kata-kata yang diyakini akan lebih berefek pada tubuh dibandingkan kata-kata yang tidak ada artinya. Dzikir membantu individu membentuk persepsi yang lain selain ketakutan yaitu keyakinan bahwa stresor apapun akan dapat dihadapi dengan baik dengan bantuan Allah. Umat islam percaya bahwa penyebutan Allah secara berulang (dzikir) dapat menyembuhkan jiwa dan menyembuhkan berbagai penyakit (Niko, 2018).

Ibu akan di dengarkan lantunan dzikir yang akan membuat ibu merasa dirinya dekat dengan Allah, berada dalam penjagaan dan lindungan-Nya, yang kemudian akan membangkitkan kepercayaan diri, kekuatan, perasaan aman, tentram, dan bahagia sehingga mampu menurunkan tingkat kecemasan ibu menjelang persalinan.

Dzikir yang digunakan dalam penelitian ini adalah dzikir jaly, dimana dzikir ini merupakan dzikir yang paling sederhana yang berisikan kalimat-kalimat Subhanallah, Alhamdulilah, Allahu Akbar. Makna yang terkandung dari kalimat dzikir Allah, Subhanallah, Alhamdulilah, Allahu Akbar, antara lain adalah bentuk kepasrahan seseorang terhadap Tuhannya, sehingga akan memunculkan harapan dan pandangan positif terhadap kehidupan serta memberikan ketenangan jiwa serta bentuk permohonan taubat kepada Tuhan sehingga akan menguatkan seseorang dalam menghadapi tantangan yang akan terjadi seperti kematian dan komplikasi akibat sakit yang dialami. Kalimat dzikir senantiasa mendorong seseorang berpikiran positif, selalu melihat sesuatu dari sisi positif, memberi makna positif dari setiap kejadian, dan bersabar terhadap kesulitan.

Dzikir akan membuat seseorang merasa tenang sehingga kemudian menekan sistem kerja syaraf simpatis dan mengaktifkan sistem kerja syaraf parasimpatis. Syaraf simpatis berfungsi dalam pengaktifan sekresi dari hormon stres, pada saat dzikir didengarkan maka sistem kerja syaraf simpatis akan ditekan dan sistem kerja syaraf parasimpatis akan diaktifkan. Saraf parasimpatis kemudian melepaskan asetilkolin untuk merangsang reseptor muscarinic (penurunan kontraksi) dari organ tersebut. Serabut sistem saraf parasimpatis akan menurunkan kerja dari serabut saraf simpatis. Lalu otak akan mengganggap tingkat kecemasan menurun, dan mengembalikan kondisi tubuh dalam keadaan normal. Ketika seseorang selalu mengucapkan kalimat positif maka kalimat positif diyakini mampu untuk menghasilkan pikiran serta emosi positif. Emosi positif mampu merangsang kerja limbic untuk menghasilkan endorphine. Endorphine mampu menimbulkan perasaan euforia, bahagia, nyaman, menciptakan ketenangan dan memperbaiki suasana hati (mood) seseorang hingga membuat seseorang berenergi (Patimah, 2015).

Menurut penelitian yang dilakukan oleh Retnowati (2011). Hasil penelitian tersebut didapatkan bahwa responden yang diberikan terapi dzikir mengalami penurunan kecemasan yang signifikan. Penelitian ini sejalan dengan penelitian Retnowati (2011) bahwa relaksasi dengan dzikir secara signifikan dapat mengurangi kecemasan responden dalam menghadapi kehamilan pertama. Hal ini terlihat dari hasil uji 
Mann Whitney $U$ yang signifikan pada taraf signifikansi 0,008 ( $p$-value $<0,01)$.

Dari hasil penelitian, teori dan penelitian terkait, peneliti menyimpulkan bahwa dari pemberian terapi dzikir berpengaruh dalam penurunan tingkat kecemasan ibu bersalin sehingga ibu lebih siap dalam menghadapi proses persalinan. Hal ini dapat dilihat dari hasil uji statistik t berpasangan.

\section{DAFTAR PUSTAKA}

Bidjuni, H., \& Kallo, V. (2014). Hubungan karakteristik ibu hamil trimester III dengan tingkat kecemasan dalam menghadapi persalinan di Poli KIA Puskesmas Tuminting. Jurnal Keperawatan, 2(2).

Fitriana, dkk. (2018). Asuhan Persalinan; Konsep Persalinan secara Komprehensif dalam Asuhan Kebidanan. Yogyakarta: Pustaka Baru Press.

Handayani, R. (2015). Faktor-Faktor Yang Berhubungan Dengan Tingkat Kecemasan Menjelang Persalinan Pada Ibu Primigravida Trimester III di Wilayah Kerja Puskesmas Lubuk Buaya Padang Tahun 2012. Ners Jurnal Keperawatan. 11(1), Maret 2015.

Hasim, R. P., \& Sulastri, S. K. (2018). Gambaran Kecemasan Ibu Hamil. [Skripsi]. Surakarta: Fakultas Ilmu Keperawatan: Universitas Muhammadiyah Surakarta).

Heriani. (2016). Kecemasan dalam Menjelang persalinan Ditinjau dari Paritas, Usia dan Tingkat pendidikan. Jurnal Ilmu Kesehatan Aisyah. 1 (2), Juli-Desember 2016.

https://ejournal.stikesaisyah.ac.id/index.ph $\mathrm{p} / \mathrm{jika} /$ article/view/14.

Huizink, A. C., Delforterie, M. J., Scheinin, N. M., Tolvanen, M., Karlsson, L., \& Karlsson, H. (2016). Adaption of pregnancy anxiety questionnaire-revised for all pregnant women regardless of parity: PRAQ-R2. Archives of women's mental health, 19(1), 125-132.

Niko, P. F. (2018). Pengaruh Terapi Dzikir Untuk Menurunkan Kecemasan Pada Ibu Hamil. Jurnal Islamika, 1(1).

Notoatmodjo, S. (2018). Metode Penelitian Kesehatan. Jakarta: Rineka Cipta

\section{SIMPULAN}

Terdapat penurunan rata-rata tingkat kecemasan ibu bersalin sebelum dan sesudah diberikan intervensi. Terdapat pengaruh teknik distraksi audio dengan media dzikir jaly terhadap penurunan kecemasan persalinan kala I fase aktif di RSUD Sekayu tahun 2020.

Nurbaiti, I. (2015). Efektivitas DzikrullahTerhadap Penurunan Kecemasan DanNyeri Persalinan Kala I Fase Aktif Ibu Primigravida. Jurnal Ners, 30-37.

Patimah, I., Suryani, S., \& Nuraeni, A. (2015). Pengaruh Relaksasi Dzikir terhadap Tingkat Kecemasan Pasien Gagal Ginjal Kronis yang Menjalani Hemodialisa. Jurnal Keperawatan Padjadjaran, 3(1).

Rahmita, N. (2017). Tingkat Kecemasan Pada Ibu Hamil Primigravida Trimester Ketiga Di Puskesmas Kecamatan Tamalanrea Makassar. Jurnal Program Studi Pendidikan Dokter.

Retnowati, S. (2011). Pengaruh pelatihan relaksasi dengan dzikir untuk mengatasi kecemasan ibu hamil pertama. Psikoislamika: Jurnal Psikologi Dan Psikologi Islam, 8(1).

Rosa, Y. (2015). Hubungan Karakteristik Dengan Tingkat Kecemasan Ibu Trimester III Dalam Menghadapi Persalinan Di Rumah Bersalin Citra Palembang Tahun 2015. Naskah Publikasi. STIK Siti Khadijah Palembang

Sagita, Y. D. (2018). Hubungan Tingkat Kecemasan dengan Lama Persalinan Kala II pada Ibu Bersalin di Rsia Anugerah Medical Center Kota Metro. Midwifery Journal: Jurnal Kebidanan UM. Mataram, 3(1), 16-20.

Said N, Kanine E, Bidjuni H. (2015). Hubungan Faktor Sosial Ekonomi Dengan Kecemasan Ibu Primigravida di Puskesmas Tuminting. Ejournal Keperawatan (eKep). $3(2), 1-8$.

Sastroasmoro, S., \& Ismael, S. (2011). Dasardasar metodologi penelitian klinis. Jakarta: Sagung Seto. 